\title{
Antecedents of Consumer Price Consciousness in a Turbulent Economy
}

DOI:

10.1111/ijcs. 12344

\section{Document Version}

Accepted author manuscript

Link to publication record in Manchester Research Explorer

\section{Citation for published version (APA):}

Hampson, D., \& McGoldrick, P. (2017). Antecedents of Consumer Price Consciousness in a Turbulent Economy. International Journal of Consumer Studies, 41(4), 404-414. https://doi.org/10.1111/ijcs.12344

\section{Published in:}

International Journal of Consumer Studies

\section{Citing this paper}

Please note that where the full-text provided on Manchester Research Explorer is the Author Accepted Manuscript or Proof version this may differ from the final Published version. If citing, it is advised that you check and use the publisher's definitive version.

\section{General rights}

Copyright and moral rights for the publications made accessible in the Research Explorer are retained by the authors and/or other copyright owners and it is a condition of accessing publications that users recognise and abide by the legal requirements associated with these rights.

\section{Takedown policy}

If you believe that this document breaches copyright please refer to the University of Manchester's Takedown Procedures [http://man.ac.uk/04Y6Bo] or contact uml.scholarlycommunications@manchester.ac.uk providing relevant details, so we can investigate your claim.

\section{OPEN ACCESS}




\title{
Antecedents of
}

\section{Consumer Price Consciousness in a Turbulent Economy}

[Alternative short-title: Antecedents of Consumer Price Consciousness]

\author{
Dr Daniel P. Hampson (corresponding author) \\ Lecturer in Marketing \\ Alliance Manchester Business School \\ The University of Manchester \\ Sackville Street Building \\ Manchester, UK \\ M1 3BB \\ Daniel.hampson@manchester.ac.uk
}

Professor Peter J. McGoldrick

Professor of Retailing

School of Materials

The University of Manchester

Sackville Street Building

Manchester, UK

M1 3BB

Peter.mcgoldrick@manchester.ac.uk

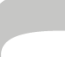

Acknowledgements:

The authors would like to thank Professor Sebastian Koos, Dr Margit Keller and Professor Triin Vihalemm for their most constructive comments and suggestions as editors for the Special Issue. We are also grateful to the anonymous reviewers of this paper.

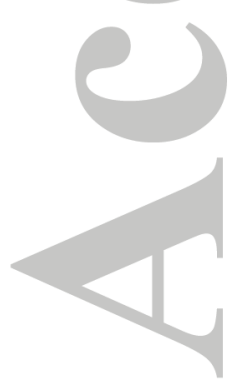

This article has been accepted for publication and undergone full peer review but has not been through the copyediting, typesetting, pagination and proofreading process which may lead to differences between this version and the Version of Record. Please cite this article as an 'Accepted Article', doi: 10.1111/ijcs.12344 


\title{
Antecedents of Consumer Price Consciousness in a Turbulent Economy
}

\author{
Abstract
}

Major economic crises create financial and normative stressors, affecting consumers long after economies technically leave recession. Consumer adaptations to these stressors challenge researchers' and marketers' assumptions of well-established concepts and theories, notably consumer price consciousness (CPC). We examine this pivotal marketing construct within the domains of stress and coping during times of economic turbulence. In this paper, the authors develop and test a conceptual model, then present implications for consumer researchers, brand marketers, and retailers.

The model focuses on the relationships between changing CPC and major economic and normative stressors, respectively financial well-being and frugality norms. To inform opportunities for specific interventions, we identify mediating roles of consumer anticipated guilt, financial fear, and smart shopper self-perception. SEM and mediation analysis test this model, based on a national survey of 1202 UK consumers. The results identify stressors that influence changing CPC, following fundamental shifts in consumer psychology and behaviour since recession. Each antecedent of CPC presents opportunities for marketers and retailers to defend or adapt brands to the challenges and opportunities presented by more price conscious consumers.

Key words: coping; price consciousness; introjection; injunctive norms; consumer guilt; economic crises. 


\section{Introduction}

Marketers and researchers have renewed interest in consumer coping strategies through times of economic crises. In the late 2000s, many major economies in the developed world suffered their worst economic crises for more than half a century. According to the traditional definition of a recession as two or more consecutive quarters of negative GDP change, the UK economy was officially in recession between April 2008 and June 2009 (ONS, 2016). During this 15 -month period, GDP contracted by $5.2 \%$ according to Office of National Statistics data, marking the most severe recession in the UK since the 1930s (ONS, 2016a). Consumer price inflation reached 5.2\% (ONS, 2016b), substantially above the broad target rate of 2\% (Bank of England, 2016).

Evidence demonstrates mixed fortunes for companies during times of economic turbulence. For some firms, economic crises lead to reduced profit margins, lost market share and even closure; survival is often a priority for these organisations (Piercy et al., 2010). For more proactive firms, recessions provide opportunities for brands to improve market share, especially those that maintain or increase their marketing efforts during these times (O'Malley et al., 2011). Brands with clear price advantages over competitors (e.g., private labels and discount retailers) tend to do well in recessions, but some premium and luxury brands also perform well and even increase prices (Piercy et al., 2010; Nunes et al., 2011).

Brands that understand changes in consumer psychology and behaviour are in a better position to turn an economic crisis and its aftermath into opportunities for long-term 
growth. Existing literature is rich with evidence of how consumers cope with recessions, notably highlighting a shift towards frugality and consumers taking greater responsibility for their present and future economic security (e.g., Zurawicki and Braidot, 2005; Kamakura and Du, 2012; Xiao et al., 2016). Major economic crises have long-term, sometimes permanent legacies on consumer behaviour and consequently marketing strategy (Deleersynder et al., 2004). Sales of private label products (Lamey et al., 2007) and the market share of discount grocery retailers (Lamey, 2014) increase during economic contractions and remain higher than before recessions, even when macroeconomic conditions improve.

However, there is scope to advance our understanding of the psychological mechanisms that explain why consumers adapt as they do. Existing literature has variously mentioned economic (e.g., Du and Kamakura, 2008), normative (Nunes et al., 2011) and affective (e.g., Piercy et al., 2010) reasons for consumer thrift in economic crises. However, in addition to limited empirical evidence, there is a tendency to treat these psychological constructs in isolation, rather than examining relationships between them. This is a serious gap, because the constructs potentially underpinning behavioural adaptions can each provide the basis of more meaningful and resonant marketing communications and branding appeals.

We address this research gap in the present study, with a focus on consumer price consciousness $(\mathrm{CPC})$, an attitudinal construct relating to the degree to which consumers focus on paying low prices (Lichtenstein et al., 1993; Kukar-Kinney et al., 2007; Zielke and Komor, 2015). CPC is the focal construct of this study for two main reasons. First, previous studies provide empirical evidence that consumers become more price conscious in recessions (Hampson and McGoldrick, 2013; Steenkamp et al., 2015). Second, CPC is a 
fundamental marketing construct, of interest and relevance to a wide range of marketing audiences. For example, previous research links CPC to a range of consumer attitudes and behaviours across multiple categories, including: fashion clothing (Moore and Carpenter, 2008); counterfeit experiential goods (Michaelidou and Christodoulides, 2011); store brands (Zielke and Komor, 2014); and ethical consumerism (Hampson and McGoldrick, 2013).

Raised CPC in times of recessions is advantageous for brands with distinct price advantages. For most other brands, CPC is challenging because it potentially narrows opportunities for differentiation. An understanding of the antecedents of CPC helps to identify opportunities to encourage consumers to consider non-price product and service attributes that may fulfil similar or complementary needs.

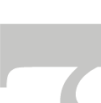

Drawing on recent literature on consumers in economic crises and theoretical and conceptual insight from the domain of stress and coping, this paper addresses the following research objectives:

1. To review existing academic literature on consumer behaviour during times of macroeconomic turbulence;

2. To understand the direct relationships between a financial stressor (i.e., reduced financial well-being), a normative stressor (i.e., frugality injunctive norm), and CPC;

3. To test the mediating roles of consumer anticipated guilt, smart shopper self-perception and financial fear on these relationships;

4. To assess the implications of the study for consumer researchers, brand marketers, and retailers. 


\section{Literature review}

\subsection{Consumer adaptations to economic crises}

Across product categories, the economic crises of the late 2000s arrested the development of some long term consumer trends (e.g., declining price consciousness (McGoldrick et al., 1999)) but accelerated others (e.g., demand for simplicity and a desire to economise (Flatters and Willmott, 2009)). During recessions, most consumers adopt more simple and savvy lifestyles that prioritise exercising greater financial prudence (Du and Kamakura, 2008;

Kamakura and Du, 2012; Strutton and Lewin, 2012; Hampson and McGoldrick, 2013). In the frequently purchased consumer goods sector, consumers cut back on purchasing products with a price premium, such as Fair Trade products (Bondy and Talwar, 2011), while increasing spending on private labels (Lamey et al., 2007) and frequenting more discount stores (Hampson and McGoldrick, 2013). In the luxury sector, consumers tend to buy less socially-conspicuous products (Kamakura and Du, 2012). Consumer durables are most affected by economic contractions because these purchases entail more performance and financial risk and are easier to postpone, relative to more habitual items (Deleersnynder et al., 2004).

\subsection{Drivers of consumer adaptations}

Researchers have highlighted various financial stressors influencing consumer adaptations to recessions, including: a decline in consumer confidence (Hampson and McGoldrick, 2013), financial insecurity (Zurawicki and Braidot, 2005); and shrunken consumption budgets (Du and Kamakura, 2008). 
However, even consumers who do not feel under added financial hardships during contractions reduce their expenditures (Deleersynder et al., 2004). In particular, discretionary and luxury spending patterns have been subjected to more social scrutiny than before the recessions of the late 2000s, potentially explaining part of the decline in spending on luxury products among some consumers (Roos, 2008; Piercy et al., 2010; Nunes et al., 2011). Consistent with the theory of relative consumption, as many consumers are forced to economise during times of economic uncertainty, the level of expenditure needed to signal social status reduces as total consumption decreases (Kamakura and Du, 2012). Opulent/non-frugal consumption habits have been labelled variously as "inappropriate" (Roos, 2008, p. 392), "wasteful" (Flatters and Wilmott, 2009, p. 4) and a sign of "showing off" (Nunes et al., 2011, p. 204). The studies mentioned in the previous sentence imply that there is a social norm that favours frugal consumer behaviour during recessions but do not formally conceptualise precisely what this norm is. We conceptualise the social norm regarding discretionary spending as an injunctive frugality norm in our model (3.2.2).

Some researchers stress the affective antecedents of consumer adaptations to economic turbulence. Simon (2009) emphasises the role of fear of the future in stifling consumer expenditures in recessions. Other academics speculate that post-recession consumers report feelings of "luxury shame" (Piercy et al., 2010, p. 6) when buying non-essential, indulgent items, necessitating some marketers to encourage "guilt-free gratification" (Grossberg, 2009, p. 6). Current studies shed little conceptual or theoretical insight into precise mechanisms through which fear and guilt impact consumers in recessions. In our model, we conceptualise the antecedents of consumer anticipated guilt (3.3.1) and financial fear (3.4.3) in recessions, and their relation to increased CPC. 
Thrift in times of economic turbulence has an intrinsic dimension. For consumers in economic crises, being savvy is less a matter of financial necessity, more a sign of being smart (Piercy et al., 2010), even fashionable (Flatters and Wilmot, 2009). Consumers shifted their pride from new and expensive products to "bragging about how little they have spent by keeping older products" (Grewal et al. 2012, p. 3). Building upon this view, we conceptualise smart shopper self-perception and describe its theoretical relations with reduced financial well-being, frugality injunctive norm and CPC (3.3.2).

\section{Model development}

In our study of how consumers adapt through times of economic turbulence, we focus on two stressors: change in subjective financial well-being (an economic stressor) and frugality injunctive norm (a normative stressor). We conceptualise CPC as an adaptive coping response to these stressors. Further, we hypothesise that increases in three affective constructs (i.e., financial fear, consumer anticipated guilt, and smart shopper selfperception), identified by researchers as prevalent in crises, (partially) mediate the relationships between the stressors and CPC. Figure 1 illustrates our hypothesised model.

\section{[Figure 1 about here]}

\subsection{Conceptual framework: stressors and coping}

Our theoretical perspective is informed by conceptual models of consumer stress (Moschis, 2007) and the broader psychology literature (Le Fevre et al., 2003). Central to these models are the concepts of stressors and coping. Potential causes of stress can be internal or external stimuli of sufficient magnitude to threaten an individual's life in a negative way 
(Moschis, 2007). Coping refers to the behavioural and cognitive ways in which individuals respond to stressors. Adaptive coping responses typically involve individuals taking steps to manage (or even eliminate) the stressor. Coping strategies that involve denying, avoiding or neglecting the stressors are maladaptive in the longer-term if they fail to tackle, and maybe even exacerbate, that stressor. Researchers seeking to explain the relationship between stressors and coping strategies have identified the important role of discrete emotions in mediating the relationships between stressors and various coping strategies (Simmons and Nelson, 2001; Le Fevre et al., 2003).

\subsection{Consumer price consciousness}

Consumer price consciousness (CPC) is an attitudinal construct measuring the extent to which consumers focus on low prices (Lichtenstein et al., 1993). CPC is therefore a significantly narrower concept than value consciousness, in which consumers make pricequality evaluations (Lichtenstein et al., 1993); for the price conscious, "lower price is better" (Ofir, 2004, p. 612). Price consciousness is largely motivated by utilitarian, rational factors (Ailawadi et al., 2001) but the price conscious perceive lower search costs, due to greater economic and psychological benefits (e.g., enjoyment) from conducting price search (KukarKinney et al., 2007). Although finding that CPC is significantly correlated with relatively stable personality trait conscientiousness, Steenkamp et al. (2015) also find that CPC is significantly less stable than other consumer traits during the course of a business cycles.

\subsection{Stressors and CPC}

\subsubsection{Reduced financial well-being}

Unlike objective measures of financial status, including income, financial well-being is a subjective evaluation of an individual's/household's financial position relative to their 
desired state, a peak in well-being at a previous point in their lives, and/or the financial wellbeing of peers (Diener et al., 2002; Prawitz et al., 2006; Sharma and Alter, 2012). In recent years, several financial stressors have become more prevalent, including unemployment, reduced consumption budgets, and financial insecurity (Sharma and Alter, 2012). A reduction in financial well-being is associated with negative consequences, such as financial deprivation (Sharma and Alter, 2012). It is a stressor because it will likely require change in spending habits. In turn, consumers might feel materially deprived, maybe even "inferior" to others in society (Sharma and Alter, 2012).

Becoming more price conscious is an adaptive coping response for people with lowered financial well-being, because this might help individuals to reduce financial outlays. When (subjective) income is lowered, so too is the opportunity cost of time; the time spent searching for lower prices usually carries higher opportunity costs when income is high (Urbany et al., 1996). Income-related constructs are significantly related to CPC, suggesting that CPC is at least partially situational rather than trait (Ailawadi et al., 2001).

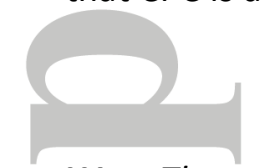

H1: There is a positive relationship between reduced subjective financial well-being and increased $C P C$.

\subsubsection{Frugality injunctive norm}

Following from discussion of social influences on consumer behaviour in recessions in the literature review, we examine the role of injunctive norms towards frugality in turbulent times. An injunctive norm is a socially shared rule of conduct tied to a sanctioning group 
(Nigbur et al., 2010); injunctive norms reflect perceptions about the potential rewards or punishment for (not) behaving in a way approved by this sanctioning group (Ajzen, 1991).

We therefore conceptualise frugality injunctive norm as a shared view that people should exercise greater financial prudence in times of economic turbulence. Although we are the first to use the term frugality injunctive norm, similar attitudes have persisted throughout history but less so in recent years. For example, certain behaviours, such as compulsive and impulsive spending, have been identified as "normatively wrong" since they indicate immaturity and wastefulness (Kwak et al., 2004, p.64). Norms can emerge when individuals' behaviour creates consumption externalities, whereby spending creates costs for others (Opp, 2001; Kotler, 2011). Opulent spending may reinforce psychological discomfort and stigma of unemployment suffered by family members, friends, and neighbours (Roos, 2008).

The power of injunctive norms therefore reflects an "it-is-dangerous-not-to-conform" ethos (Park and Lessig, 1977, p. 103). According to self-categorization theory, many individuals define their personal identity through their matrix of social relationships (Christensen et al., 2004; Mellor et al., 2008), therefore an individual's self-evaluation is affected by how others within a reference group perceive them (Leary et al., 2003). Reflecting on need for interpersonal connections, the Baumeister and Leary (1995) belongingness hypothesis reasons that individuals have innate need for "a minimum quantity of lasting, positive, and significant interpersonal relationships" (p. 497). Therefore, consumers have a social interest in developing favourable attitudes to price searching and saving, as measured by CPC.

H2: There is a positive relationship between increased frugality injunctive norm and increased $C P C$. 


\subsection{Affective (mediating) constructs}

\subsubsection{Consumer anticipated guilt}

Consumer guilt is a negative affective state, associated with uncomfortable feelings such as loneliness, anxiety and insecurity (Baumeister et al., 1995). Feelings of guilt arise from a consumer's appraisal of personal responsibility for an undesirable event resulting from a violation of a personal standard or moral norm through a consumption-related action (Niedenthal et al., 1994; Dahl et al., 2005; Watson and Spence, 2007). We focus specifically on consumer anticipated guilt. Compared to reactive consumer guilt, where the transgression has already occurred, consumers experience anticipatory consumer guilt when contemplating a potential violation of standards (Huhmann and Brotherton, 1997).

In relation to reduced financial well-being, we anticipate that consumers spending on more discretionary, luxury items is felt to be wrong because a) it is a controllable behaviour that b) might exacerbate the original stressor, thereby creating difficulties for oneself and dependents (Alonso et al., 2013).

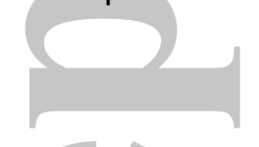

H3: There is a positive relationship between reduced financial well-being and increased consumer anticipated guilt.

Guilt also arises from the thought of violating a social, injunctive norm (Dahl et al., 2003). The social antecedent of guilt reflects individuals' empathic dimension (Olthof, 2012), deriving from "altruism and concern about others" (O'Connor et al., 1997, p.75). Ultimately,

“people experience positive emotions when affirming the injunctive norms of groups and 
negative emotions when violating them" (Christensen et al., 2004, p.1297). Because the guilt is triggered by influences in the external social environment, it does not reflect selfdetermined behaviour (Deci and Ryan, 2000). Instead, the motivational property of guilt is described more appropriately as introjective (Thøgersen, 2006). The anticipated guilt is extrinsic, emanating from external forces, but also partially internalized, because of public consciousness and empathic involvement (Plant and Ryan, 1985), therefore more likely maintained over time (Deci and Ryan, 2000).

H4: There is a positive relationship between increased frugality injunctive norm and increased consumer anticipated guilt

Individuals seek to avoid negative emotions because they are uncomfortable and cause psychological harm. CPC is a suitable response to the financial and normative stressors discussed in this study, therefore useful in avoiding potentially harmful implications of not adapting. Consistent with literature stressing the greater influence of guilt on shopping decisions (Piercy et al., 2010; Nunes et al., 2011; Alonso et al., 2013), we expect that:

H5: There is a positive relationship between increased consumer anticipated guilt and increased $C P C$.

\subsubsection{Smart shopper self-perception}

Grewal et al. (2012) argue that in turbulent economies, consumers derive feelings of pride by being thrifty, but provide limited theoretical rationale. Pride is a positive emotion related 
to self-attributed achievement, with success an internal reward for having exercised skill, competence, and effort to achieve something that the average person has not achieved (Bodolica and Spraggon, 2011). This study focuses on a very specific type of pride: smart shopper self-perception (SSSP). Defined as "an ego-related variable pertaining to consumers' need for intrinsic rewards from price savings achieved through shopping" (Garretson et al., 2002, p. 94), SSSP provides a sense of "accomplishment" (Schindler, 1988: 450) and boost to self-esteem (Mano and Elliot, 1997).

Given the habitual nature of many purchases and the centrality of consumption to people's self-concepts and even happiness, it is difficult to alter consumption styles. Therefore, exercising greater financial prudence is challenging but this form of pride offers self-ascribed positive affect.

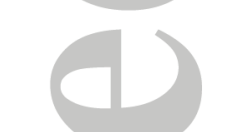

H6: There is a positive relationship between reduced subjective financial well-being and increased smart shopper self-perception.

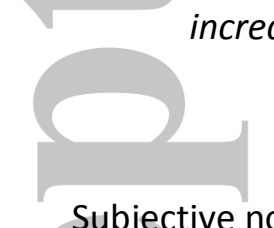

Subjective norms are externally imposed standards of behaviours, which consumers might feel violate their independence and sovereignty. In the context of economic crises, many people do not feel financially affected and retain a desire for those behaviours that the frugality injunctive norm chastises (Quelch and Jocz, 2009). Nevertheless, due to theory discussed in relation to $\mathrm{H} 2$, such consumers engage in these behaviours anyway. This can create psychological imbalance between desires and behaviours, which might be uncomfortable for individuals. To reconcile this problem, consumers might internalise the 
frugality norm in such a way that frugal behaviour offers intrinsic rewards. Such consumers might not need to be more frugal, therefore feeling "smart" for doing so.

H7: There is a positive relationship between increased frugality injunctive norm and increased smart shopper self-perception.

The literature provides evidence that smart shopper feelings are related to consumer constructs closely related to $\mathrm{CPC}$, including minimising money expenditure and seeking utilitarian value (Atkins and Kim, 2012), comparison shopping (Mittal, 2016), and private label and discount purchases (Liu and Wang, 2008). CPC is therefore a mechanism through which people can derive extrinsic rewards during times of economic crisis.

$r(1$

H8: There is a positive relationship between increased smart shopper self-perception and increased consumer price consciousness.

\subsubsection{Financial fear}

Simon (2009) identifies fear as a one of the most powerful determinants of recessionary shopping adaptations but provide little conceptual or theoretical insight into this psychological construct. Like guilt, fear is a negative emotion that is often experienced with uncomfortable affective states such as anxiety (Borkovec et al, 1998; Brosschot et al., 2006). Fear tends to lead to more pessimistic risk assessments than other negative emotions such as anger, because fear involves perceptions of uncertainty and lack of direct control over 
the situation (Watson and Spence, 2007). In our study, the object the fear appraisal emanates from consumers' negative appraisals of their future financial situations.

Recent research examines how increased money worry and anxiety continue to relate negatively to consumers' subjective evaluation of their wealth (Gasiorowska, 2014). Fear does not disappear quickly (Gullone, 2000); Knabe and Rätzel (2011) comment that "unemployment 'scars' because it 'scares'” (p. 283). We believe that reduced financial wellbeing creates fear because of many problems that diminished wealth can create, including material deprivation and various psychological and psychosocial issues (Feather, 2012). r

H9: There is a positive relationship between reduced subjective financial well-being and increased financial fear

Fearful people feel threatened, which can evoke action towards self-protection (Brennan and Binney, 2010). For people with financial fear in particular, adopting a more price conscious mind-set is a rational and adaptive coping mechanism to mitigate the stress and negative consequences associated financial fear. Because CPC allows consumers to reduce spending, they might be able to increase their precautionary savings, which might help to protect themselves better from the negative financial implications of potential but uncertain financial contingencies, such as redundancies or pay decreases (Tokuoka, 2013).

H10: There is a positive relationship between financial fear and consumer price consciousness. 


\section{Method}

\subsection{Research context}

Our empirical data collection was completed in September 2009. Technically, the UK had been out of recession for three months (although this was not known until January 2010), but economic turbulence continued. Indicatively, at $7.9 \%$ the unemployment rate was higher (and still rising) in September 2009 than at any time during the recession (see Figure

2) and did not return to pre-recession lows of 5\% until the end of 2015 (ONS, 2016c). Fears of a double-dip recession did not materialise but GDP did not return to pre-recession levels for several years after the recession (see Figure 2); GDP growth was negative in Q2 and Q4 2012 (ONS, 2016a).

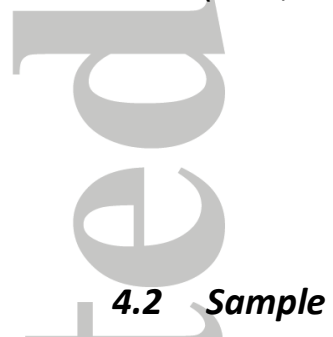

[Figure 2 about here]

Data were collected via an online survey of UK shoppers, using quota sampling by age, gender and main region to achieve a broadly representative national sample. Respondents were qualified by screening questions that ensured they were at least 18 years old and one of the main shoppers in their household. A total of 1311 respondents participated in the survey, but 109 cases (8.3\%) were rejected after checks on excessive straight-lining or fast responding. We had a final useable sample of 1,202 respondents. The respondents range from $18-80$ years $(M=45.92)$ and $52.7 \%$ are female. Approximately $40 \%$ of respondents hold a university degree. The mean annual income for the households was $£ 33,785$. 


\subsection{Measures}

It is common for researchers to measure changes in consumer attitudes and behaviours via self-report in cross sectional research designs (e.g., Sharma and Alter, 2012), especially in studies of consumers in recessions (e.g., Bondy and Talwar, 2011; Hampson and McGoldrick, 2013; Zurawicki and Braidot, 2005). Therefore, each of the constructs in our model was operationalised to measure the direction and magnitude of change since the beginning of the recession. While experimental approaches, such as those used by Millet et al. (2012), enable laboratory simulation of cues associated with macroeconomic conditions, longitudinal survey studies cannot control or predict recession timings, also risking validity problems including carry-over effects (see: Hampson and McGoldrick, 2013, p.833).

Existing scales with evidence of reliability and construct validity measure increased CPC (Lichtenstein et al., 1993), increased consumer anticipated guilt (Cotte et al., 2005) and, increased smart shopper self-perception (Burton et al., 1998). Our reduced financial wellbeing scale is consistent with Sharma and Alter (2012). The increased frugality injunctive norm scale was influenced by existing subjective norm scales that reflected other people's judgment of people's behaviour (e.g., Rhodes and Courneya, 2003). The increased financial fear scale was developed based upon items from the Panas-X scale (Watson and Clark, 1999). Appendix 1 lists items for all six scales. An in-store survey of sixty retail shoppers tested scales for internal consistency; face validity was judged by four academics experienced in development of marketing and consumer behaviour scales. The constructs were measured on 7 point Likert scales ( $1=$ disagree strongly; $7=$ agree strongly). Table 1 provides descriptive, reliability and discriminant validity statistics. 


\section{[Table 1 about here]}

\subsection{Common method biases}

In line with recommendations of Podsakoff et al. (2003) we incorporated multiple measures

to minimise $\mathrm{CMB}$. A priori, anonymity was assured to minimise acquiescence bias, and filler

tasks involving text entries or different response formats separated scales, to inhibit repetitive responding. The Harman's (1976) test showed that a single factor accounts for $43 \%$ of variance between the constructs, below the $50 \%$ threshold for $\mathrm{CMB}$ concerns, especially as a proportion of common variance is not attributable to method. The fit statistics reported below further confirm that inter-construct and item correlations are not excessive.

\subsection{Model fit, scale reliabilities, and construct validity}

Confirmatory factor analysis (maximum likelihood procedure) supports the measurement model, in terms of absolute fit measures $\left(x^{2} / d f=4.49 ; \mathrm{GFI}=.939 ; \mathrm{RMSEA}=.054 ;\right.$ SRMR $=$ $.047)$ and incremental fit measures (NFI $=.969 ; \mathrm{CFI}=.976)$. Evidence supports the convergent validity of the measurement model: the smallest standardized factor loading of any of the items is .661, which is well above the .50 rule-of-thumb threshold (Hair et al., 2010). Average variance extracted (AVE) ranges from .64 (reduced financial well-being) to .91 (increased frugality injunctive norm) and reliability alphas all exceed .80 (see Table 1). The scales demonstrate discriminant validity, according to the Fornell and Larker (1981) criteria: inter-construct correlations range from .286 (increased frugality injunctive norm $\leftrightarrow$ increased consumer price consciousness) and .670 (increased financial fear $\leftrightarrow$ reduced financial well-being); the square of the correlation between each pair of constructs is lower 
than the AVE for associated constructs. This provides confidence in the unidimensionality of the six sets of items, and how the constructs relate to other measures.

\section{Results}

Structural equations modelling (SEM) using AMOS 22 tested the hypothesised relationships. The fit of the structural model is satisfactory: $\mathrm{x}^{2} / \mathrm{df}=4.98 ; \mathrm{GFI}=.930 ; \mathrm{RMSEA}=.058 ; \mathrm{SRMR}=$ $.076 ; \mathrm{NFI}=.964 ; \mathrm{CFI}=.971$. Standardised item loadings are virtually unchanged from the CFA results.

The results support all but two hypotheses, tested by examining the estimated standardized structural path estimates (see Table 2). Hypothesis 2, which predicted a positive relationship between increased frugality injunctive norm (FIN) and CPC, is not supported. We undertook a mediation analysis to explore the FIN $\rightarrow$ CPC relation in more depth, using the bootstrapping method devised by Preacher and Hayes (2004), with 1000 bootstrap samples. In step 1 of the mediation model, the regression of FIN on CPC, ignoring the mediators (but controlling for reduced financial well-being and financial fear), is significant, $\mathrm{b}=.110, \mathrm{t}(1198)=4.25, \mathrm{p}=.000)$. At step 2 , the regression of FIN on both moderators is also significant (on CAG: $b=.133, t(1198)=5.62, p=.000 ;$ on SSSP: $b=.316, t(1198)=$ $.12 .65, \mathrm{p}=.000)$. The third step shows that both mediators, controlling for FIN, were significant predictors of CPC, CAG $(b=.129, t(1196)=4.49, p-.000)$ and SSP $(b=.381$, $t(1196)=12.51, p=.000)$. Step four shows that, controlling for the two mediators, FIN was not a significant predictor of $C P C(b=.018, t=.721, p=.471)$. A Sobel test found that the FIN was mediated by CAG $(z=4.22, p=.000)$ and SSP $(z=5.11, p=.000)$. 
Increased financial fear does not have a significant relationship with increased CPC, contrary to Hypothesis 10. We explore potential theoretical reasons for lack of support for this hypothesis in the next section.

\section{[Table 2 about here]}

\section{Discussion}

\subsection{Theoretical contributions}

The results examine interrelationships between several concepts that have gained increased salience since the onset of recession from 2008, including: smart shopper self-perception, consumer anticipated guilt, frugality injunctive norm, financial fear, and reduced financial well-being. These concepts emerged from recent, largely theoretical papers on consumers in crises. Our work is among the first that operationalises these constructs and tests multiple relationships between them.

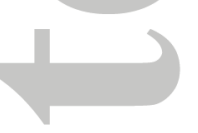

The analyses generally support theory and hypotheses presented in section 3 . However, two hypotheses were not supported. One unanticipated finding was that frugality injunctive norm is not significantly directly associated with CPC in the structural model (contrary to $\mathrm{H} 2$ ). A potential reason for this finding is that many of the behaviours associated with CPC (e.g., store-brand purchases, store disloyalty and spatial price search) are not always publicly conspicuous and therefore not likely to be subject to social scrutiny/awareness. Our analysis does show alternatively that that the relationship between frugality injunctive norm and CPC is fully mediated by consumer anticipated guilt and smart shopper self-perception. 
This is an important elaboration of the relationship and consistent with evidence that guilt appeals in advertising may succeed, when guilt is based on violation of a social norm (Basil et al., 2006). Externally imposed sanctions are replaced by the threat of internally imposed sanctions (i.e., consumer anticipated guilt) and intrinsic reward (smart shopper selfperception). This is consistent with Ryan and Deci's (2000) concept of introjected regulation. This form of internal regulation occurs when acting in accord with an externally imposed standard, without fully accepting the standard as one's own (Deci et al., 1991; Ryan and Deci, 2000). The individual does not personally identify with the external regulation so it is not part of the self (Deci et al., 1991). Social sanctions are replaced by internal coercion through guilt (Deci et al., 1991; Ryan and Deci, 2000; Thørgensen, 2006) but might also be internalised in such a way to derive intrinsic reward (smart shopper self-perception).

Hypothesis 10, predicting a positive relationship between financial fear and CPC, also was not supported. Fear is an anticipatory emotion, currently experienced but in relation to a future, uncertain event (Brosschot et al., 2006). Although not consistent with our theory, there is an argument in the literature that fear is less conducive to adaptive coping strategies than positive affect and other discrete negative emotions, such as guilt. Fear is an uncomfortable psychological state that can encourage consumers to deny the existence of and/or avoid thinking about the stressor (Le Fevre et al., 2003).

These results also broaden the known nomological network of CPC, a fundamental marketing construct that regained greater salience since the recession. Antecedents of CPC have typically been considered at the category level, research indicating that consumers are more price-conscious in product categories where they perceive lower price-quality 
associations (Sinha and Batra, 1999). At an individual level, studies have limited their focus to income and income-related determinants of CPC, finding that lower income is associated with greater CPC (Ailawadi et al., 2001). Our research further identifies normative and affective antecedents of CPC.

\subsection{Marketing implications}

Raised CPC in times of macroeconomic contractions presents opportunities for discount and price-led brands to build market share. However, for brands that usually compete on nonprice factors, raised CPC threatens the competitiveness of their value propositions. Our study provides ideas on how these brands might either increase or reduce consumers' tendency towards CPC in times of recession.

The finding that reduced financial well-being has a direct impact on CPC highlights the importance in recognising that recessions alter consumers' ability to buy as before. From a product perspective, retailers might want to consider increasing the availability of own-label fighter lines. Discount brands are advised to focus even more prominently on their costbenefit advantages through price-oriented advertising appeals. These could incorporate money-related appeals in their marketing communications and branding during economic contractions, for example through greater use of comparative advertising.

For brands aspiring to maintain premium and luxury positioning strategies, reducing prices is a less attractive option due to the potentially negative impacts on their long-term brand reputations. These brands must overcome consumer financial resistance by reducing

perceived financial risks and relieving the consumer of money anxiety. For example, 
companies could offer special guarantees, more competitive credit terms or extended warranty periods. These brands might also promote the idea that being price-conscious is not economically wise, especially in the long-term. They can promote their product as a better financial choice by emphasising lifetime costs, rather than drawing attention to their higher original purchase costs during times of turbulence. For example, P\&G used 'performance-based value messaging' during the recession, which promoted products such as Tide detergent on the basis that they save money by doing a better job (Piercy et al., 2010).

In addition to economic stressors, our other findings highlight affective antecedents of CPC in recessions, in particular, consumer anticipated guilt and smart shopper self-perception, which might offer bases for advertising appeals. Brands for which raised CPC is a challenge might develop ways to quell feelings of guilt associated with discretionary spending during economic turbulence. Marketers may mitigate negative affect by focusing more on positive affect in their communications. For example, Quelch and Jocz (2009) encourage marketers to remind consumers "you deserve it" and to position small indulgences as morale raisers. Zurawicki and Braidot (2005) find a rise in consumer ethnocentrism in recessions, which suggests that brands could offer guilt reduction by encouraging consumer spending on goods benefitting their national economy.

There are various monetary and non-monetary strategies that marketers can use to satiate consumers' desire to feel they have made smarter consumption choices during turbulent times. One common tactic employed in the grocery retail sector is to increase promotion of own-label offerings, specifically stressing their price-quality value proposition relative to 
national brand alternatives. For example, in the US, Kmart launched explicitly focused on the 'smart' theme when launching its "Smart sense" product range during the contraction.

In the UK, Aldi had success with its "Like brands, only cheaper" campaign. Sales promotions can trigger "smart shopper" feelings, because consumers may feel that they have secured a bargain within a narrow time-window. Using coupons can be especially effective in creating smart shopper feelings, because coupon usage usually requires some effort, for some creating a sense of achievement that other promotions do not (Laroche et al., 2003).

Brands that maintain high prices or even increase prices during recessions tend to induce consumer perceptions of price unfairness (Ferguson, 2014), which would, intuitively, impede these brands from being a "smart" consumption choice. To mitigate the threat of perceived price unfairness, firms might instead downsize products or increase price transparency, offering automatic rebates and/or price-matching guarantees (Ferguson, 2014).

\subsection{Limitations and Extensions}

Although based on a large data set, reliance on cross-sectional quantitative data limits scope to test causality. The empirical study is based on UK consumers, so additional theoretical insight could be derived from replicating this study across other populations and cultures. A major difference between recent and earlier post-recession eras is the abundance of online price information, available at home or on the move, rendering traditional approaches to price de-sensitisation less effective. Thus there is great scope for further research into the interactions between $\mathrm{CPC}$ and retail and/or product marketing strategies, as previous

assumptions need re-testing in this information-rich environment (Grewal et al., 2012). 


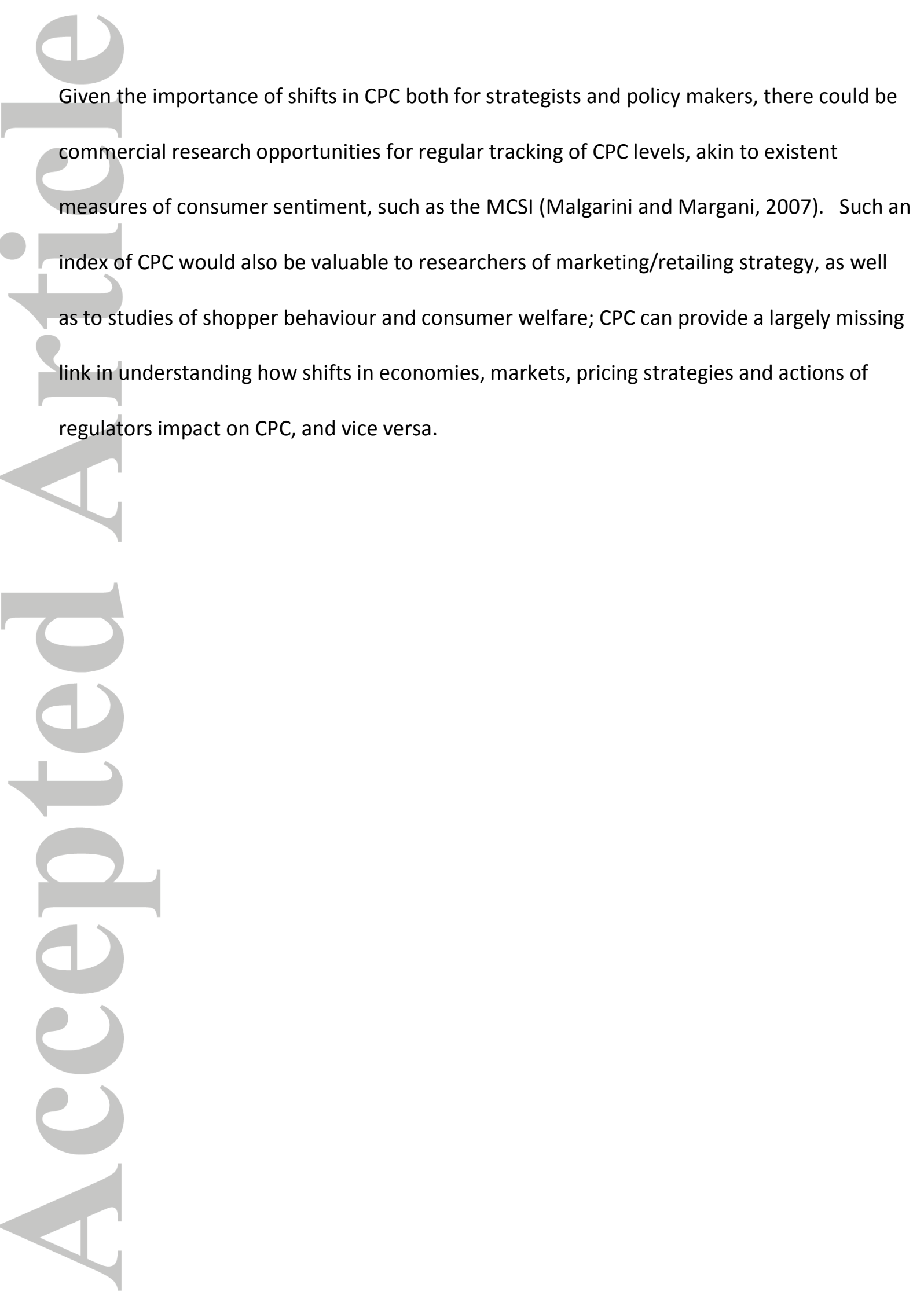




\section{References}

Ailawadi, K., Neslin, S. \& Gedenk, K. (2001) Pursuing the value conscious consumer: store brands versus national brand promotions. Journal of Marketing, 65, 71-89.

Ajzen, I. (1991) The Theory of Planned Behaviour. Organisational Behaviour and Human Decision Processes, 50, 179-211.

Alonso, L.E., Rodríguez, C.J.F. \& Rojo, R.I. (2013) From consumerism to guilt: economic crisis and discourses about consumption in Spain. Journal of Consumer Culture, doi: $10.1177 / 1469540513493203$.

Atkins, K.G. \& Kim, Y.K. (2016) Smart apparel shopping: a multidimensional and genderneutral measure. Clothing and Textiles Research Journal, 34, 3-19.

Bank of England (2016) Monetary policy framework. [WWW document] URL: http://www.bankofengland.co.uk/monetarypolicy/Pages/framework/framework.aspx (last accessed 31st October 2016).

Basil, D.Z., Ridgway, N.M. \& Basil, M.D. (2006) Guilt appeals: the mediating effect of responsibility. Psychology \& Marketing, 23, 1035-1054.

Baumeister, R.F., Reis, H.T. \& Delespaul, P.A. (1995) Subjective and experiential correlates of guilt in daily life. Personality and Social Psychology Bulletin, 21, 1256-1268.

Baumeister, R.F. \& Leary, M.R. (1995) The need to belong: desire for interpersonal attachments as a fundamental human motivation. Psychological Bulletin, 117, 497-529.

Bodolica, V. \& Spraggon, M. (2011) Behavioral governance and self-conscious emotions: unveiling governance implications of authentic and hubristic pride. Journal of Business Ethics, 100, 535-550.

Bondy, T. \& Talwar, V. (2011) Through thick and thin: how fair-trade consumers have reacted to the global economic recession. Journal of Business Ethics, 101, 365-383. 
Borkovec, T.D., Ray, W.J. \& Stöber, J. (1998) Worry: a cognitive phenomenon intimately linked to affective, physiological, and interpersonal behavioral processes. Cognitive Therapy and Research, 22, 561-576.

Brennan, L. \& Binney, W. (2010) Fear, guilt, and shame appeals in social marketing. Journal of Business Research, 63, 140-146.

Brosschot, J.F., Gerin, W. \& Thayer, J.F. (2006) The perspective cognition hypothesis: a review of worry, prolonged stress-related physiological activation, and health. Journal of Psychosomatic Research, 60, 113-124.

Burton, S., Lichtenstein, D.R., Netemeyer, R.G. \& Garretson, J.A. (1998) A scale for measuring attitude toward private label products and an examination of its psychological and behavioural correlates. Journal of the Academy of Marketing Science, 26, 293-306.

Christensen, P.N., Rothgerber, H., Wood, W. \& Matz, D.C. (2004) Social norms and identity relevance: a motivational approach to normative behaviour. Personality and Social Psychology Bulletin, 30, 1295-1309.

Cotte, J., Coulter, R.A. \& Moore, M. (2005) Enhancing and disrupting guilt: the role of ad credibility and perceived manipulative intent. Journal of Business Research, 58, 361-368.

Dahl, D.W., Honea, H. \& Manchanda, R.V. (2003) The nature of self-reported guilt in consumption contexts. Marketing Letters, 14, 159-171.

Deci, E.L., Vallerand, R.J., Pelletier, L.G. \& Ryan, R.M. (1991) Motivation and education: the self-determination perspective. Educational Psychologist, 26, 325-346.

Deci, E.L. \& Ryan, R.M. (2000) The 'what' and 'why' of goal pursuits: human needs and the self-determination of behaviour. Psychological Inquiry: An International Journal for the Advancement of Psychological Theory", 11, 227-268.

Deleersnyder, B., Dekimpe, M.G., Sarvary, M. \& Parker, P.M. (2004) Weathering tight economic times: the sales evolution of consumer durables over the business cycle. Quantitative Marketing and Economics, 2, 347-383. 
Diener, E. \& Biswas-Diener, R. (2002) Will money increase subjective well-being? Social Indicators Research, 57, 119-169.

Du, R.Y. \& Kamakura, W.A. (2008) Where did all that money go? Understanding how consumers allocate their consumption budget. Journal of Marketing, 72, 109-131.

Feather, N.T. (2012) The psychological impact of unemployment. Springer Science \& Business Media, Chicago.

Ferguson, J.L. (2014) Implementing price increases in turbulent economies: pricing approaches for reducing perceptions of price unfairness. Journal of Business Research, 67, 2732-2737.

Flatters, P. \& Willmott, M. (2009) Understanding the post-recession consumer. Harvard Business Review, 87, 106-112.

Fornell, C. \& Larcker, D. F. (1981) Evaluating structural equation models with unobservable variables and measurement error. Journal of Marketing Research, 18, 39-50.

Garretson, J. A., Fisher, D. \& Burton, S. (2002) Antecedents of private label attitude and national brand promotion attitude: similarities and differences. Journal of Retailing, 78, 91 99.

Garretson, J.A. \& Burton, S. (2003) Highly coupon and sale prone consumers: benefits beyond price savings. Journal of Advertising Research, 43, 162-172.

Gasiorowska, A. (2014) The relationship between objective and subjective wealth is moderated by financial control and mediated by money anxiety. Journal of Economic Psychology, 43, 64-74.

Grewal, D., Roggeveen, A.L., Compeau, L.D. \& Levy, M. (2012) Retail value-based pricing strategies: new times, new technologies, new consumers. Journal of Retailing, 88, 1-6.

Grossberg, K.A. (2009) Marketing in the Great Recession: an executive guide. Strategy \& Leadership, 37, 4-8. 
Gullone, E. (2000) The development of normal fear: a century of research. Clinical Psychology Review, 20, 429-451.

Hair, J.F., Black, W.C., Babin, B.J. \& Anderson, R.E. (2010) Multivariate Data Analysis, $7^{\text {th }}$ edn. Prentice Hall, Upper Saddle River, NJ.

Hampson, D.P. \& McGoldrick, P.J. (2013) A typology of shopping patterns in recession. Journal of Business Research, 66, 831-838.

Harman, H.H. (1976) Modern Factor Analysis. University of Chicago Press, Chicago.

Huhmann, B.A. \& Brotherton, T.P. (1997) A content analysis of guilt appeals in popular magazine advertisements. Journal of Advertising , 26, 35-45.

Kamakuru, W.A. \& Du, R.Y. (2012) How economic contractions and expansions affect expenditure patterns. Journal of Consumer Research, 39, 229-247.

Knabe, A. \& Rätzel, S. (2011) Scarring or scaring? The psychological impact of past unemployment and future unemployment risk. Economica, 78, 283-293.

Kotler, P. (2011) Reinventing marketing to manage the environmental imperative. Journal of Marketing, 75, 132-135.

Kukar-Kinney, M., Walters, R.G. \& MacKenzie, S.B. (2007) Consumer responses to characteristics of price-matching guarantees: the moderating role of price consciousness. Journal of Retailing, 83, 211-221.

Kwak, H., Zinkhan, G.M. \& Lester Roushanzamir, E.P. (2004) Compulsive comorbidity and its psychological antecedents: a cross-cultural comparison between the US and South Korea. Journal of Consumer Marketing, 21, 418-434.

Lamey, L. (2014) Hard economic times: a dream for discounters. European Journal of Marketing, 48, 641-656.

Lamey, L., Deleersynder, B., Dekimpe, M.G. \& Steenkamp, J.-B.E.M. (2007) How business cycles contribute to private-label success: evidence from the United States and Europe. Journal of Marketing, 71, 1-15. 
Laroche, M., Pons, F., Zgolli, N., Cervellon, M.-C. \& Kim, C. (2003) A model of consumer response to two retail sales promotion techniques. Journal of Business Research, 56, 513522.

Le Fevre, M., Matheny, J. \& Kolt, G.S. (2003) Eustress, distress, and interpretation in occupational stress. Journal of Managerial Psychology, 18, 726-744.

Leary, M.R., Gallagher, B., Fors, E., Buttermore, N., Baldwin, E., Kennedy, K. \& Mills, A. (2003) The invalidity of disclaimers about the effects of social feedback on self-esteem. Personal and Social Psychology Bulletin, 29, 623-636.

Levy, M. \& Weitz, B. (2012) Retail Management. McGraw-Hill Irwin, New York, NY.

Levy, M., Grewal D., Peterson, R.A. \& Connolly, B. (2005) The concept of the 'Big Middle'. Journal of Retailing, 81, 83-88.

Lichtenstein, D.R., Ridgway, N.M. \& Netemeyer, R.G. (1993) Price perceptions and consumer shopping behaviour. Journal of Marketing Research, 30, 234-245.

Liu, T.C. \& Wang, C.Y. (2008) Factors affecting attitudes toward private labels and promoted brands. Journal of Marketing Management, 24, 283-298.

Malgarini, M. \& Margani, P. (2007) Psychology, consumer sentiment and household expenditures. Applied Economics, 39, 1719-1729.

Mano, H. \& Elliot, M.T. (1997) Smart shopping: the origins and consequences of price savings. Advances in Consumer Research, 24, 504-510.

McGoldrick, P.J., Betts, E.J. \& Wilson, A.F. (1999) Modelling consumer price cognition: evidence from discount and superstore sectors. Service Industries Journal, 19, 171-193.

Mellor, D., Stokes, M., Firth, L., Hayashi, Y. \& Cummins, R. (2008) Need for belonging, relationship satisfaction, loneliness, and life satisfaction. Personality and Individual Differences, 45, 213-218. 
Millet, K., Lamey, L. \& Van den Bergh, B. (2012) Avoiding negative vs. achieving positive outcomes in hard and prosperous economic times. Organizational Behavior and Human Decision Processes, 117, 275-284.

Mittal, B. (2016) Psychographics of comparison shoppers. Journal of Consumer Marketing, 33, 20-31.

Moore, M. \& Carpenter, J. (2006) The effect of price as a marketplace cue on retail patronage. Journal of Product \& Brand Management, 15, 265-271.

Moschis, G.P. (2007) Stress and consumer behavior. Journal of the Academy of Marketing Science, 35, 430-444.

Niedenthal, P.M., Tangney, J.P. \& Gavanski, I. (1994) If only I weren't' versus 'if only I hadn't': distinguishing shame and guilt in counterfactual thinking. Journal of Personality and Social Psychology, 67, 585-595.

Nigbur, D., Lyons, E. \& Uzzell, D. (2010) Attitudes, norms, identity and environmental behaviour: using an expanded theory of planned behaviour to predict participation in a kerbside recycling programme. British Journal of Social Psychology, 49, 259-284.

Nunes, J.C., Drèze, X. \& Han, Y.J. (2011) Conspicuous consumption in a recession: toning it down or turning it up? Journal of Consumer Psychology, 21, 199-205.

O'Connor, L.E., Berry, J.W., Weiss, J., Bush, M. \& Sampson, H. (1997) Interpersonal guilt: development of a new measure. Journal of Clinical Psychology, 53, 73-89.

Office for National Statistics (2016a) Gross Domestic Product. [WWW document] URL: http://www.ons.gov.uk/economy/grossdomesticproductgdp (last accessed 31st October 2016).

Office for National Statistics (2016b) Inflation and price indices. [WWW document] URL: https://www.ons.gov.uk/economy/inflationandpriceindices (last accessed 31st October 2016). 
Office for National Statistics (2016c). Unemployment. [WWW document] URL:

https://www.ons.gov.uk/employmentandlabourmarket/peoplenotinwork/unemployment (last accessed 31st October 2016).

Ofir, C. (2004) Re-examining latitude of price acceptability and price thresholds: predicting basic consumer reaction to price. Journal of Consumer Research, 30, 612-621.

Olthof, T. (2012) Anticipated feelings of guilt and shame as predictors of early adolescents' antisocial and pro-social interpersonal behaviour. European Journal of Developmental Psychology, 9, 371-388.

O'Malley, L., Story, V. \& O'Sullivan, V. (2011) Marketing in a recession: retrench or invest? Journal of Strategic Marketing, 19, 285-310.

Opp, K-D. (2001) How do norms emerge? An outline of a theory. Mind and Society, 2, $101-$ 128.

Park, C.W. \& Lessig, V.P. (1977) Students and housewives: differences in susceptibility to reference group influence. Journal of Consumer Research, 4, 102-110.

Piercy, N.F., Cravens, D.W. \& Lane, N. (2010) Marketing out of the recession: recovery is coming, but things will never be the same again. The Marketing Review, 10, 3-23.

Plant, R.W. \& Ryan, R.M. (1985) Intrinsic motivation and the effects of self-consciousness, self-awareness, and ego-involvement: an investigation of internally controlling style. Journal of Personality, 53, 435-449.

Podsakoff, P.M., MacKenzie, S.B., Lee, J.Y. \& Podsakoff, N.P. (2003) Common method biases in behavioral research: a critical review of the literature and recommended remedies. Journal of Applied Psychology, 88, 879-903.

Prawitz, A.D., Garman, E.T., Sorhaindo, B., O'Neill, B., Kim, J. \& Drentea, P. (2006) InCharge financial distress/financial well-being scale: development, administration, and score interpretation. Journal of Financial Counseling and Planning, 17, 34-50. 
Preacher, K.J., \& Hayes, A.F. (2004) SPSS and SAS procedures for estimating indirect effects in simple mediation models. Behavior Research Methods, Instruments, \& Computers, 36, 717-731.

Quelch, J. \& Jocz, K. (2009) How to market in a downturn. Harvard Business Review, 87, 5262.

Rhodes, R.E. \& Courneya, K.S. (2003) Investigating multiple components of attitude, subjective norm, and perceived control: an examination of the theory of planned behaviour in the exercise domain. British Journal of Social Psychology, 42, 129-146.

Roos, M.W.M. (2008) Willingness to consume and ability to consume. Journal of Economic Behaviour and Organisation, 66, 387-402.

Ryan, R.M. \& Deci, E.L. (2000) Self-determination theory and the facilitation of intrinsic motivation, social development, and well-being. American Psychologist, 55, 68-78.

Schindler, R.M. (1989) The excitement of getting a bargain: some hypotheses concerning the origins and effects of smart-shopper feelings. Advances in Consumer Research, 16, 447-453.

Sharma, E. \& Alter, A.L. (2012) Financial deprivation prompts consumers to seek scarce goods. Journal of Consumer Research, 39, 545-560.

Simon, H. (2009) The crisis and customer behaviour: eight quick solutions. Journal of Customer Behaviour, 8, 177-186.

Simmons, B.L., \& Nelson, D.L. (2001) Eustress at work: the relationship between hope and health in hospital nurses. Health Care Management Review, 26, 7-18.

Sinha, I. \& Batra, R. (1999) The effect of consumer price consciousness on private label purchase. International Journal of Research in Marketing, 16, 237-251.

Steenkamp, J.B.E. \& Maydeu-Olivares, A. (2015) Stability and change in consumer traits: evidence from a 12-year longitudinal study, 2002-2013. Journal of Marketing Research, 52, 287-308. 
Strutton, D. \& Lewin, J. (2012) Investigating consumers' responses to the Great Recession. Journal of Consumer Marketing, 29, 378-388.

Thøgersen, J. (2006) Norms for environmentally responsible behaviour: an extended taxonomy. Journal of Environmental Psychology, 26, 247-261.

Tokuoka, K. (2013) Saving response to unemployment of a sibling. Journal of Economic Behavior \& Organization, 89, 58-75.

Urbany, J.E., Dickinson, P.E. \& Kalapurakal, R. (1996) Price search in the retail grocery market. Journal of Marketing, 60, 91-104.

Watson, D. \& Clark, L.A. (1999) The PANAS-X: Manual for the positive and negative affect . schedule. [WWW document] URL

http://ir.uiowa.edu/cgi/viewcontent.cgi?article=1011\&context=psychology pubs (last accessed $31^{\text {st }}$ May 2016)

Watson, L. \& Spence, M.T. (2007) Causes and consequences of emotions on consumer behaviour: a review and integrative cognitive appraisal theory. European Journal of Marketing, 41, 487-511.

Xiao, J.J., \& O'Neill, B. (2016) Consumer financial education and financial capability. International Journal of Consumer Studies. DOI: 10.1111/ijcs.12285

Zielke, S. \& Komor, M. (2015) Cross-national differences in price-role orientation and their impact on retail markets. Journal of the Academy of Marketing Science, 43, 159-180.

Zurawicki, L. \& Braidot, N. (2005) Consumers during crisis: responses from the middle class in Argentina. Journal of Business Research, 58, 1100-1109. 
Table 1 Descriptive statistics and correlation analyses

\begin{tabular}{|l|c|c|c|c|c|c|c|c|c|}
\hline \multirow{3}{*}{} & \multicolumn{3}{|c|}{$\begin{array}{c}\text { Descriptives and } \\
\text { reliability }\end{array}$} & \multicolumn{5}{c|}{$\begin{array}{c}\text { Inter-construct correlations** below the diagonal; } \\
\text { Average variance extracted on the diagonal; squared } \\
\text { correlations above diagonal }\end{array}$} \\
\cline { 2 - 12 } & Mean* & S.D & Alpha & 1 & 2 & 3 & 4 & 5 & 6 \\
\hline 1. CPC & 4.66 & 1.47 & .925 & $(.75)$ & .082 & .138 & .130 & .169 & .088 \\
\hline 2. FIN & 4.18 & 1.71 & .976 & .286 & $(.91)$ & .220 & .147 & .255 & .088 \\
\hline 3. RFW & 4.42 & 1.63 & .836 & .371 & .469 & $(.64)$ & .449 & .259 & .100 \\
\hline 4. FF & 5.05 & 1.40 & .936 & .360 & .384 & .670 & $(.76)$ & .167 & .123 \\
\hline 5. CAG & 4.08 & 1.62 & .944 & .411 & .505 & .509 & .409 & $(.80)$ & .215 \\
\hline 6. SSSP & 5.18 & 1.34 & .948 & .489 & .297 & .317 & .351 & .464 & $(.83)$ \\
\hline
\end{tabular}

Key: $\mathrm{CPC}=$ Consumer price consciousness; $\mathrm{FIN}=$ frugality injunctive norm; RFW = reduced financial well-being; FF = financial fear; CAG = consumer anticipated guilt; SSSP = Smart shopper self-perception.

Note:* measured on 7 -point scales ( $1=$ disagree strongly, 7 = agree strongly); ** all correlations significant $\mathrm{p} \leq .01$;

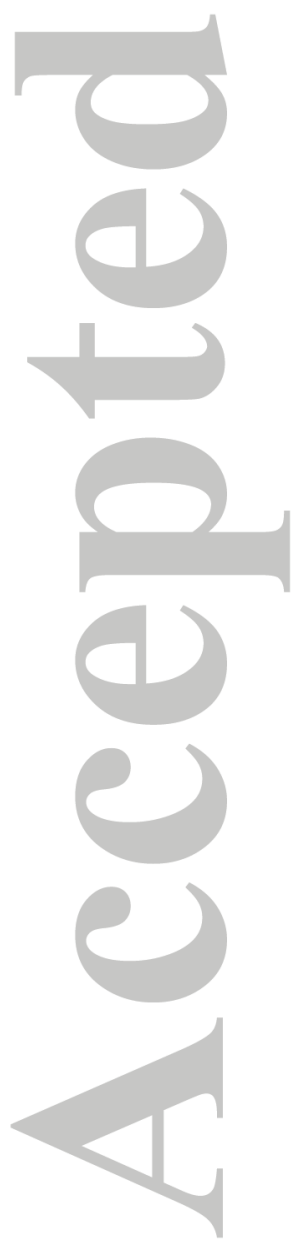


Table 2 Standardized path estimates

\begin{tabular}{|l|c|c|c|}
\hline Hypothesized relationship & Coeff. & C.R. & p. \\
\hline H1: Reduced financial well-being $\rightarrow$ Consumer price consciousness & .136 & 2.748 & .006 \\
\hline H2: Frugality injunctive norm $\rightarrow$ Consumer price consciousness & .025 & .788 & .431 \\
\hline H3: Reduced financial well-being $\rightarrow$ Consumer anticipated guilt & .396 & 11.581 & $* * *$ \\
\hline H4: Frugality injunctive norm $\rightarrow$ Consumer anticipated guilt & .317 & 10.663 & $* * *$ \\
\hline H5: Consumer anticipated guilt $\rightarrow$ Consumer price consciousness & .132 & 3.854 & $* * *$ \\
\hline H6: Reduced financial well-being $\rightarrow$ Smart shopper self-perception & .316 & 8.673 & $* * *$ \\
\hline H7: Frugality injunctive norm $\rightarrow$ Smart shopper self-perception & .139 & 4.229 & $* * *$ \\
\hline H8: Smart shopper self-perception $\rightarrow$ Consumer price consciousness & .374 & 12.708 & $* * *$ \\
\hline H9: Reduced financial well-being $\rightarrow$ Financial fear & .69 & 19.562 & $* * *$ \\
\hline H10: Financial fear $\rightarrow$ Consumer price consciousness & .069 & 1.786 & .074 \\
\hline
\end{tabular}

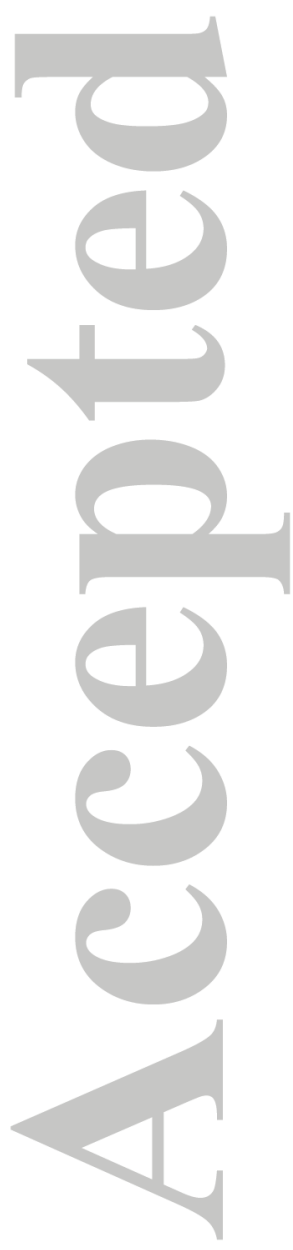




\section{Appendix 1 Scale constructs}

\section{Items}

\section{Reduced financial well-being}

Compared with before the recession...

...my financial position has worsened.

.... have less to spend on extras than most of my peers.

...my ability to spend on non-essential items has been reduced.

\section{Increased frugality injunctive norm}

Since the recession, it is more likely that ...

...my friends and relatives would think that I am unwise for spending money on luxuries.

...people close to me would think I was being reckless if I spent money on things I do not need.

... if I spend money on non-essentials, it would be seen as irresponsible by those around me.

\section{Increased financial fear}

Compared with before the recession...

... am more fearful about my financial future.

... am more afraid that life will be difficult in the future.

... am more scared about my financial situation.

\section{Increased consumer anticipated guilt}

Because of the recession, it is more likely that...

...if I made purchases that are avoidable, I would feel guilty.

...I would feel ashamed, if I spent more than I needed to.

...I would feel it was irresponsible if I spent more than necessary.

\section{Increased smart shopper self-perception}

Since the beginning of the recession it is more likely that...

...I feel clever when I save money whilst shopping.

...saving money whilst shopping makes me feel good.

...saving money when shopping gives me a sense of winning.

...I feel proud of myself when I have got a good deal.

\section{Increased price consciousness}

Because of the recession...

... am more willing to go to extra effort to find lower prices.

... am more likely to shop at more than one store to take advantage of low prices.

... believe more that money saved by finding lower prices is usually worth the time.

... believe more that the time it takes to find low prices is worth the effort.

Note: all scales measured on 7-point Likert scales ( 1 = disagree strongly; 7 = agree strongly). 
Figure 1 Theoretical model
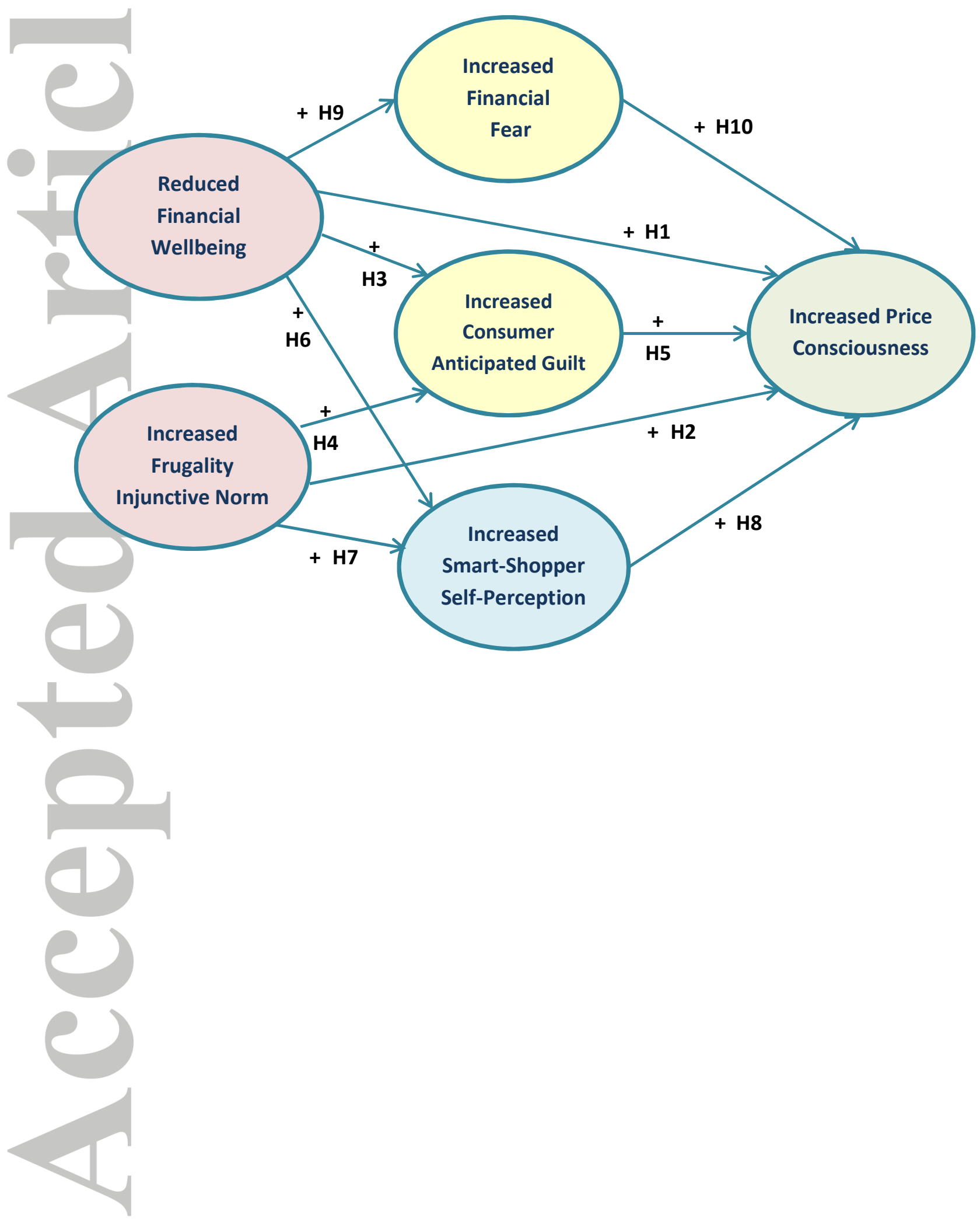
Figure 1 UK unemployment rate and GDP (chained volume measure, seasonally adjusted) $2007-2013$

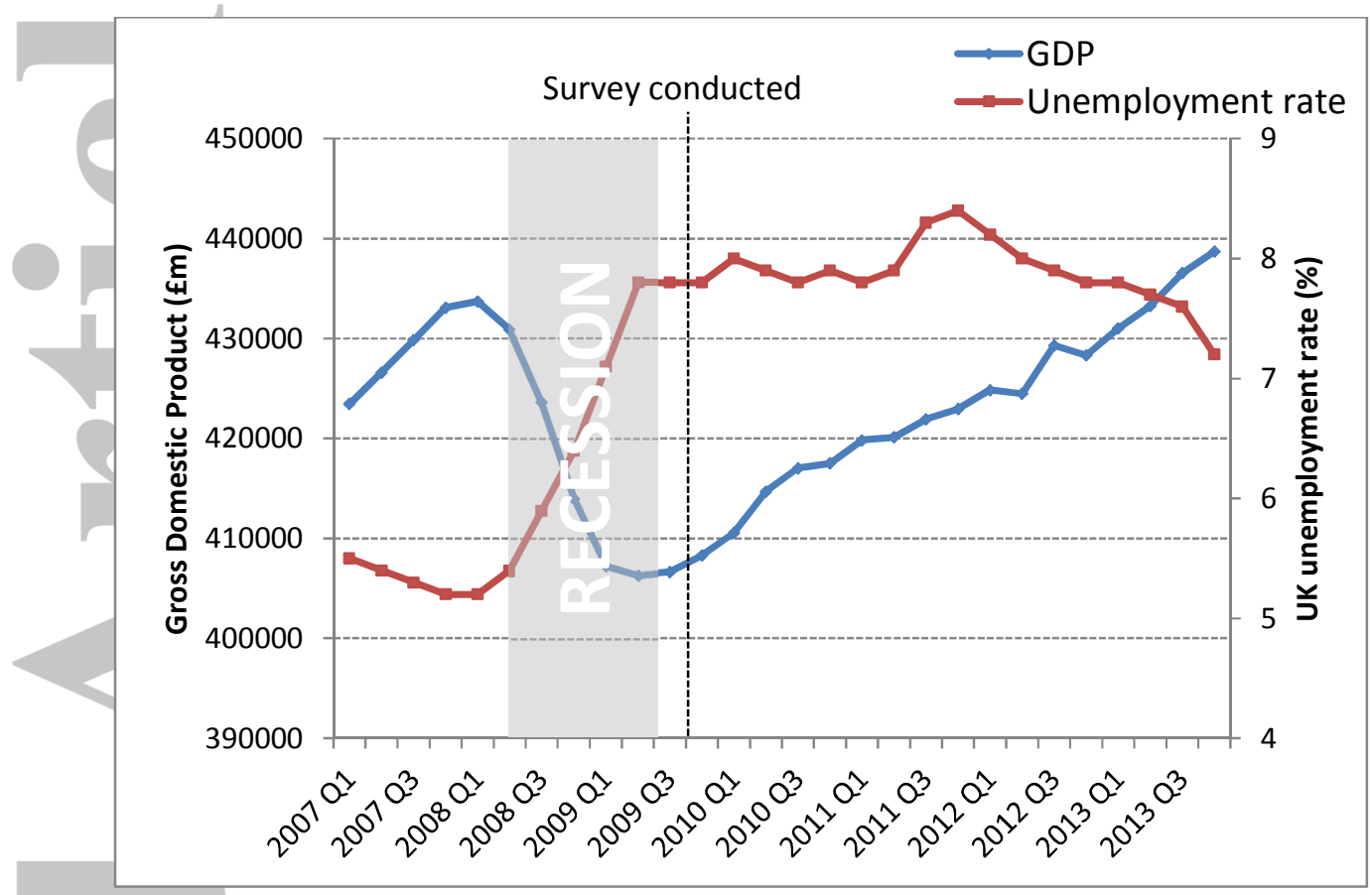

Data sources: GDP ONS (2016a); Unemployment rate: ONS (2016c)

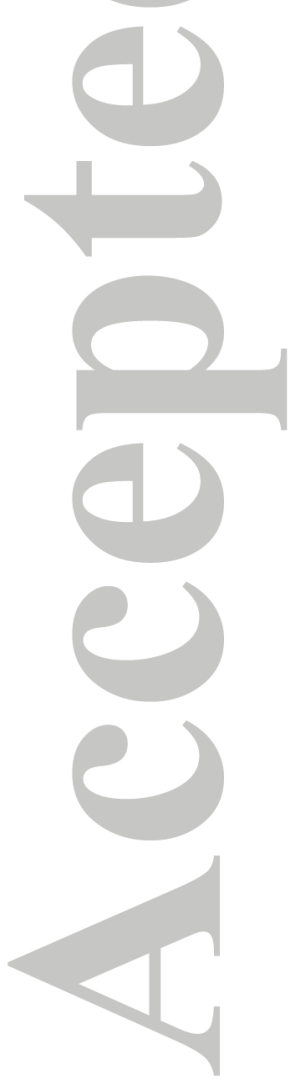

